\title{
ANALISIS PENGARUH PEMBERDAYAAN WANITA PEDAGANG SEKTOR INFORMAL TERHADAP PENINGKATAN PENDAPATAN RUMAH TANGGA
}

\author{
Agung Yatiningrum ${ }^{*}$, Joni Hendra ${ }^{1}$, Saifullah ${ }^{1}$ \\ ${ }^{1}$ Universitas Panca Marga Probolinggo \\ *agungyatiningrum2@gmail.com
}

\begin{abstract}
The purpose of this study is to analyze the influence the women empowerment of informal sector traders related to factors (capital, number of working hours, number of labor, business location, effort experience, and level of education) to increasing of household income. The population in this study were female workers in informal trading business (business stalls) in the Leces Probolinggo District with a sample of 100 respondents.

The data analysis uses multiple linear regression. The result of the analysis proves that the factors (capital, number of working hours, number of labor, business location, business experience, education level) have significant influence to the increasing of household income as simultan. The number of working hours has the dominant effect in increasing their income. If they want to increase their income, they should increase the number of working hours. While the capital and education level does not have a significant influence in increasing of household income
\end{abstract}

Keywords: Capital, Business Hours, Labor, Business Location, Business Experience, Education Level And Household Income.

\section{PENDAHULUAN}

Dalam masyarakat yang berada pada ekonomi subsistem atau golongan berpendapatan rendah partisipasi wanita dalam lapangan kerja dilakukan guna mempertahankan ekonomi rumah tangga. Para wanita tersebut mengalokasikan segala daya yang dimiliki seperti waktu, ketrampilan dan sumber dana guna mempertahankan kelangsungan hidup dengan menjadi pencari nafkah kedua (secondary breadwinner). Bahkan pada situasi dimana penghasilan suami tidak menentu, tidak mencukupi, atau tidak mempunyai penghasilan maka wanita menjadi penopang utama ekonomi keluarga (Indraswari dan Thamrin, 2006).

Di daerah perkotaan strategi kelangsungan hidup yang dilakukan oleh angkatan kerja wanita antara lain melalui aktivitas ekonomi di sektor informal. Berbagai macam aktivitas ekonomi informal dikerjakan oleh wanita dengan tetap mempertimbangkan alokasi waktu bagi keluarga dan pekerjaan rutin rumah tangga. Temuan dari berbagai hasil penelitian menunjukkan bahwa kegiatan usaha di sektor informal, khususnya sektor perdagangan, memang dapat diharapkan untuk menunjang ekonomi rumah tangga (Jafar, 2007; Widaningroem; Sunaryo, dan Djasmani, 2009).

Dengan demikian, upaya untuk meningkatkan kesejahteraan masyarakat melalui pemberdayaan wanita pedagang sektor informal guna meningkatkan pendapatan rumah tangga menjadi menarik dan penting untuk dilakukan. Selain itu, pemberdayaan wanita pedagang sektor informal mempunyai peran penting untuk 
mengurangi ketimpangan distribusi pendapatan dan memberikan konstribusi besar dalam menanggulangi dalam masalah pengangguran (Gilbert dan Gugler, 2006).

Salah satu aktivitas ekonomi informal yang banyak dikerjakan wanita adalah usaha warung rumah tangga. Pada umumnya usaha ini merupakan kegiatan rumah yang dijalankan di rumah atau di sekitar rumah (home-based production). Dengan demikian untuk melakukan kegiatan produksi maka wanita tidak perlu meninggalkan rumah sehingga tetap dapat menjalankan kegiatan rutin rumah tangga. Di samping itu usaha warung memiliki posisi dan fungsi yang penting dalam mendistribusikan kebutuhan sehari-hari masyarakat sekitarnya. Hasil survei yang pernah dilakukan Asosiasi Pengecer dan Pertokoan Indonesia (AP3I) mengungkapkan bahwa pangsa pasar dari usaha warung mencapai prosentase $26,79 \%$ dan seluruh konsumen yang berbelanja di Indonesia (Setyawan, A.A dan M.Fatchurachman 2005).

Selain memiliki beberapa keunggulan kompetitif, usaha warung juga menghadapi sejumlah kendala dalam pengembangan usahanya. Sebagai unit kegiatan ekonomi yang beroperasi menetap di kawasan pemukiman, usaha warung mengalami kendala dalam meningkatkan pangsa pasarnya. Dalam hal ini usaha warung mengalami gejala yang disebut dengan istilah keterbatasan permintaan (Harper, 2005). Dalam pada itu omzet usaha warung juga sangat tergantung pada kenaikan konsumsi atau jumlah uang yang dapat dibelanjakan masyarakat sekitarnya. Tanpa adanya peningkatan pendapatan masyarakat lingkungan bisnisnya maka sulit diharapkan adanya peningkatan daya beli dan tingkat konsumsi (Hardjono, 2006).

Keterlibatan pilihan wanita dalam sektor riil untuk menunjang perekonomian keluarga dapat memberikan kontribusi yang berbeda-beda tergantung dari kondisi perekonomian masing-masing rumah tangga. Mengingat arti penting usaha warung rumah tangga maka perlu dipikirkan langkahlangkah kebijakan yang dapat mendorong usaha tersebut meningkatkan pendapatan dan skala usahanya. Untuk itu diperlukan pemahaman yang lebih mendalam terhadap faktor-taktor yang menentukan pendapatan usaha keluarga. Melalui pemahaman yang akurat terhadap faktor-taktor yang dimaksud maka diharapkan dapat menjadi bahan pertimbangan akademik guna menyusun paket kebijakan pengembangan usaha warung yang tepat pada sasaran.

Kondisi perempuan yang tersubordinatif dalam mengakses kehidupan ekonomi menjadikan perempuan sebagai kelompok yang rentan. Hal itu terlihat jelas pada perempuan yang bekerja di sektor informal. Oleh karena itu, penanganan perempuan yang bekerja di sektor informal akan menjadikan suatu potensi ekonomi yang tinggi bagi kesejahteraan keluarga. Usaha-usaha sektor informal itu tidak bisa lepas dari peran perempuan dalam sektor domestik. Daya tahan terhadap usaha disebabkan oleh tingkat kemandirian perempuan yang tinggi. Oleh karena itu, diperlukan penanganan dengan kebijakan yang berkelanjutan dan memberikan akses lebih besar terhadap sumber permodalan formal (Adi, Pidekso: 2003).

Motivasi perempuan bekerja pada saat ini semakin kompleks, namun yang lebih utama adalah untuk mengatasi persoalan ekonomi keluarganya. Kontribusi pendapatan merupakan sumbangan yang diberikan kepada rumah tangganya oleh perempuan bekerja, dengan indikator jumlah pendapatan yang diterima dan jumlah uang yang diberikan kepada rumah tangganya. Sedangkan Ekonomi keluarga merupakan keseluruhan kebutuhan ekonomi keluarga, yang terdiri dari kebutuhan ekonomi seharihari/pangan, kebutuhan pendidikan dan kebutuhan kesehatan. Penelitian ini bertujuan menganalisis pengaruh pemberdayaan wanita pedagang sektor informal yang terkait dengan faktor-faktor (modal, jumlah jam kerja, jumlah tenaga kerja, lokasi usaha, pengalaman berusaha, dan tingkat pendidikan) terhadap peningkatan pendapatan rumah tangga. 
Faktor-faktor eksternal dan internal yang mempengaruhi pendapatan pedagang

Pada usaha perdagangan ada beberapa faktor yang mempengaruhi peningkatan produksi yang pada akhirnya akan mempengaruhi tingkat pendapatan yang akan diterima oleh pedagang sektor informal. Adapun variabel-variabel yang mempengaruhi tingkat pendapatan adalah: modal usaha, lama usaha, jam kerja pedagang, fasilitas parkir dan lokasi usaha.

\section{Modal Usaha}

Menurut Sawir (2003) modal kerja adalah keseluruhan aktiva lancar yang dimiliki oleh perusahaan atau dapat pula dimaksudkan dana yang harus tersedia untuk membiayai operasi perusahaan. Karena modal sangat menunjang sekali dalam kelancaran kegiatan perusahaan, sebagai contoh bagian produksi membutuhkan bahan baku, maka mereka harus membeli dulu bahan tersebut atau bagian pemasaran akan melakukan kegiatan promosi guna mengenalkan barang atau jasa yang mereka tawarkan pada konsumen atau bagian personalia membutuhkan pegawai baru, untuk itu dilakukan kegiatan perekrutan karyawan baru. Sedangkan menurut Riyanto (2002) modal adalah barang konkrit yang ada dalam rumah tangga perusahaan yang tercantum di neraca debet maupun daya beli atau nilai tukar disebelah kredit. Menurut Sutrisno (2012) menyatakan bahwa modal kerja adalah dana yang diperlukan oleh perusahaan untuk memenuhi kebutuhan operasional perusahaan sehari-hari, seperti pembelian bahan baku, pembayaran upah buruh, membayar hutang dan pembayaran lainnya.

\section{Jam Kerja}

Analisis jam kerja merupakan bagian dari teori ekonomi mikro, khususnya pada teori penawaran tenaga kerja yaitu tentang kesediaan individu untuk bekerja dengan harapan memperoleh penghasilan atau tidak bekerja dengan konsekuensi mengorbankan penghasilan yang seharusnya didapatkan. Kesediaan tenaga kerja untuk bekerja dengan jam kerja panjang atau pendek adalah merupakan keputusan individu (Nicholson, 2011). Menurut Ehrenberg dan Smith (1988) keputusan untuk bekerja merupakan suatu keputusan puncak mengenai bagaimana seharusnya memanfaatkan waktu. Cara umum bagi orang-orang untuk memanfaatkan waktunya adalah dengan cara bekerja. Oleh karena itu dapat digolongkan pekerjaan itu menjadi pekerjaan yang tidak mendapatkan nafkah dengan pekerjaan mendapatkan nafkah. Jam kerja pedagang pasar seni atau jam buka kios mempengaruhi jumlah tamu yang terlayani karena pembeli tidak pasti jam kedatangannya (Artawa, 2012).

\section{Jumlah Tenaga Kerja}

Penelitian Santayani (1996) dan Syahruddin (1987) membuktikan bahwa penggunaan tenaga kerja oleh usaha perdagangan informal mempengaruhi tingkat pendapatannya. Dengan tambahan jumlah tenaga kerja, memungkinkan adanya pelayanan yang lebih baik kepada konsumen, baik dalam arti kualitas maupun kuantitas layanan. Penelitian Syahruddin tersebut dilakukan di Kota Padang dengan responden terdiri dari unit-unit usaha perdagangan dan jasa di sektor informal.

\section{Lokasi usaha}

Merencanakan suatu usaha perlu memilih letak lokasi usaha yang strategis untuk mudah dijangkau konsumen (Dewi, Vera Laksmi, 2012). Menurut Alcacer (2004) dengan lokasi yang berdekatan dengan pesaing usaha, perusahaan dapat melakukan strategi kompetisi total baik dalam kepemimpinan harga atau jasa lain yang diberikan. Seorang pengusaha harus mengenali jumlah dan ukuran usaha lain serta situasi persaingan yang ada di daerah tersebut, lokasi dapat mudah dijangkau dan mudah dikenali.

Fasilitas parkir merupakan fasilitas pelayanan umum yang merupakan faktor sangat penting dalam sistem transportasi di daerah perkotaan (Alamsyah, 2005). Menurut keputusan Menteri Perhubungan 
No: 66 tahun 1993, parkir adalah keadaan tidak bergerak suatu kendaraan yang tidak bersifat sementara. Terciptanya lokasi parkir yang aman dan nyaman diharapkan akan dapat meningkatkan perekonomian di pasarpasar seni tradisional.

\section{Pengalaman Berusaha}

Dalam menjalankan suatu usaha, lama usaha memegang peranan penting dalam proses melakukan usaha perdagangan (Widya Utama, 2012). Lamanya suatu usaha dapat menimbulkan suatu pengalaman berusaha, diamana pengalaman dapat mempengaruhi pengamatan seseorang dalam bertingkah laku (Asmie, 2011). Lama pembukaan usaha dapat mempengaruhi tingkat pendapatan, lama seorang pelaku bisnis menekuni bidang usahanya akan mempengaruhi produktivitasnya sehingga dapat menambah efisiensi dan menekan biaya produksi lebih kecil daripada penjualan (Firdaus, 2013). Semakin lama menekuni bidang usaha perdagangan akan makin meningkatkan pengetahuan tentang selera dan perilaku konsumen serta semakin banyak relasi bisnis dan pelanggan (Asmie, 2011).

\section{Tingkat Pendidikan}

Pendidikan merupakan salah satu indikator kualitas sumber daya manusia. Seorang pelaku usaha yang berpendidikan tinggi akan memiliki kualitas dan daya saing relatif lebih baik dibanding yang tidak berpendidikan. Pada usaha perdagangan informal yang sangat kompetitif, setiap pelakunya dituntut kreatif dan inovatif. Dengan demikian pelaku usaha yang terdidik memiliki peluang yang lebih besar untuk meraih tingkat pendapatan yang lebih tinggi. Hal ini terbukti dari hasil studi Arjana (1997) terhadap pedagang kaki lima di Kota Kupang.

\section{METODE}

Jenis penelitian yang digunakan dalam penelitian ini adalah penelitian deskriptif kuantitatif, sedangkan data yang digunakan adalah data primer. Penentuan sampel didasarkan kriteria berikut :
1. Usaha warung rumah tangga yang beroperasi di dalam kampung dan bukan di pinggir jalan raya.

2. Metode operasinya menetap atau tidak berpindah-pindah.

3. Jenis mata perdagangannya, yaitu kelontong (warung kelontong), sayur mayur (warung sayur), dan makanan olahan (warung makan).

Dalam penelitian ini pengambilan sampel dilakukan dengan menentukan tingkat presisi melalui error maksimum sebesar 0,20 dengan tingkat keyakinan 95\%,

Dengan demikian besarnya sampel yang diambil berjumlah 100 responden dan penelitian ini dilaksanakan di Kecamatan Leces KabupatenProbolinggo. Lokasi ini dipilih karena merupakan salah satu wilayah selatan Kota Probolinggo yang cukup menonjol fenomena unit kegiatan ekonomi informalnya.

\section{Analisis Data}

Untuk melakukan pembuktian hipotesis, penelitian ini menggunakan metode analisis statistik. Analisis statistik digunakan untuk membuktikan adanya pengaruh dari modal usaha, jam kerja, jumlah tenaga kerja terhadap pendapatan. Pengujian dilakukan dengan menggunakan model regresi berganda dengan metode kuadrat terkecil biasa yang dapat dirumuskan sebagai berikut:

$$
\mathrm{Y}={ }_{{ }^{\mathrm{b}} 0+{ }^{\mathrm{b}} 6}{ }^{\mathrm{b}} 1 \mathrm{x}_{1}+{ }^{\mathrm{b}} 2 \mathrm{x}_{2}+{ }^{\mathrm{b}} 3 \mathrm{x}_{3}+\mathrm{b}_{4} \mathrm{x}_{4}+{ }^{\mathrm{b}} 5^{\mathrm{X}} 5+
$$

$$
\begin{aligned}
& \text { Dimana } \\
& \mathrm{Y}_{1}=\text { Tingkat Pendapatan } \\
& \mathrm{x}_{1}=\text { Jumlah Modal Usaha } \\
& \mathrm{x}_{2}=\text { Jam Kerja } \\
& \mathrm{x}_{3}=\text { Jumlah Tenaga Kerja } \\
& \mathrm{x}_{4}=\text { Lokasi Usaha } \\
& \mathrm{x}_{5}=\text { Pengalaman Berusaha } \\
& \mathrm{x}_{6}=\text { Tingkat Pendidikan } \\
& { }_{0} 0=\text { Intersep } \\
& \mathrm{b} 1, \mathrm{~b} 2, \mathrm{~b} 3, \mathrm{~b} 4, \mathrm{~b} 5, \mathrm{~b} 6=\text { Koefisien Regresi } \\
& \mathrm{X} 1, \mathrm{X} 2, \mathrm{X} 3, \mathrm{X} 4, \mathrm{X} 5, \mathrm{X} 6
\end{aligned}
$$


Untuk menguji hipotesis yang dikemukakan, maka digunakan uji $\mathrm{t}$ dan uji F. Uji t dimaksudkan untuk mengetahui variabel bebas yang berpengaruh secara signifikan terhadap variabel tidak bebas (terikat) secara individual. Sedangkan uji F digunakan untuk mengetahui apakah secara bersama-sama variabel-variabel bebas tersebut dapat menjelaskan variabel terikat.

\section{HASIL DAN PEMBAHASAN \\ Hasil}

Tabel 1. ANOVA

\begin{tabular}{l|r|r|r|r|r}
\hline & Sumof & \multicolumn{2}{c}{ Mean } \\
Model & Squares & Df & Square & F & Sig. \\
\hline 1 Regression & 95,018 & 6 & 15,836 & 295,644 &, $000^{\mathrm{b}}$ \\
\hline Residual & 4,982 & 93 & 0,054 & & \\
\hline Total & 100 & 99 & & & \\
\hline
\end{tabular}

Sumber: data diolah

Pada tabel 1 diatas nampak bahwa sig $\mathrm{F}<0,05$ berarti hipotesis diterima artinya variabel X1,X2,X3,X4,X5,X6 (modal, jumlah jam kerja, jumlah tenaga kerja, lokasi usaha, pengalaman berusaha, tingkat pendidikan) secara bersama-sama mempunyai pengaruh yang signifikan terhadap pendapatan wanita pedagang sektor informal di Kecamatan Leces Kabupaten Probolinggo.

Tabel 2. Hasil Analisis Regresi Berganda

\begin{tabular}{|c|c|c|c|c|c|}
\hline \multirow{3}{*}{ Model } & Unstand & dized & \multirow{4}{*}{$\begin{array}{c}\begin{array}{c}\text { Standardiz } \\
\text { ed }\end{array} \\
\text { Coefficient } \\
\text { s } \\
\text { Beta }\end{array}$} & \multirow{4}{*}{$\mathrm{t}$} & \multirow{4}{*}{ Sig. } \\
\hline & \multicolumn{2}{|c|}{ Coefficients } & & & \\
\hline & B & Std. & & & \\
\hline & & Error & & & \\
\hline 1 (Constant) & 2,106 & 0,487 & & 4,328 & 0 \\
\hline $\mathrm{X} 1$ & $-0,011$ & 0,013 & $-0,012$ & $-0,848$ & 0,401 \\
\hline & & & & & \\
\hline $\mathrm{X} 2$ & 2,284 & 0,073 & 1,141 & 31,207 & 0 \\
\hline $\mathrm{X} 3$ & 0,33 & 0,032 & 0,147 & 10,382 & 0 \\
\hline $\mathrm{X} 4$ & 0191 & 0.022 & 0225 & 8743 & 0 \\
\hline$\Delta 4$ & 0,191 & 0,022 & $0,22 J$ & 0,745 & 0 \\
\hline & & & & & \\
\hline $\mathrm{X} 5$ & 0,06 & 0,027 & 0,068 & 2,175 & 0,035 \\
\hline & & & & & \\
\hline X6 & $-0,009$ & 0,014 & $-0,009$ & $-0,62$ & 0,538 \\
\hline
\end{tabular}

Sumber: data diolah
Pada tabel 2 diatas dapat diperoleh hasil estimasi dari penelitian adalah sebagai berikut:

$\mathrm{Y}=2,106+-, 011 \mathrm{X} 1+2,284 \mathrm{X} 2+, 330 \mathrm{X} 3+$ , $191 \mathrm{X} 4+, 060 \times 5+-, 009 \mathrm{X} 6$

Dari persamaan di atas, hasil yang dapat di jelaskan sebagai berikut: 1) nilai constant sebesar 2,106 Artinya apabila (modal, jumlah jam kerja, jumlah tenaga kerja,lokasi usaha, pengalaman berusaha, lama pendidikan) tidak ada (0) maka pendapatan wanita pedagang sektor informal akan sebesar 2,106 satuan; 2) Koefisien modal (b1) sebesar -,011 artinya jika modal wanita pedagang sektor informal mendapatkan pinjaman $1 \%$ maka pendapatan wanita akan turun 0,11 sebaliknya jika jumlah pinjaman menurun $1 \%$ maka tingkat pendapatan wanita pedagang meningkat 0,11 ; 3) Koefisien jumlah jam kerja (b2) sebesar 2,284 artinya jika jumlah jam kerja wanita pedagang meningkat $1 \%$ maka pendapatan wanita akan meningkat 2,284 sebaliknya jika jumlah jam kerja menurun $1 \%$ maka tingkat pendapatan wanita pedagang menurun sebesar 2,284; 4) Koefisien jumlah tenaga kerja (b3) sebesar 0,330 artinya jika jumlah tenaga kerja wanita pedagang meningkat $1 \%$ maka pendapatan wanita akan meningkat 0,330 sebaliknya jika jumlah tenaga kerja menurun $1 \%$ maka tingkat pendapatan wanita pedagang menurun sebesar 0,330 ; 5) Koefesien lokasi usaha (b4) sebesar 0,191 artinya jika lokasi usaha wanita pedagang meningkat/lebih strategis $1 \%$ maka pendapatan wanita akan meningkat 0,191 sebaliknya jumlah tanggungan keluarga menurun $1 \%$ maka tingkat pendapatan wanita pedagang menurun sebesar 0,191 ; 6) Koefesien pengalaman berusaha (b5) sebesar 0,060 artinya jika pengalaman berusaha wanita pedagang meningkat $1 \%$ maka pendapatan wanita akan meningkat 0,060 sebaliknya bila pengalaman berusaha menurun $1 \%$ maka tingkat pendapatan wanita pedagang menurun sebesar 0,060 ; 7) Koefesien tingkat pendidikan (b6) sebesar $-0,009$ artinya jika 
lama pendidikan wanita pedagang meningkat $1 \%$ maka pendapatan wanita akan turun 0,009 sebaliknya bila lama pendidikan menurun $1 \%$ maka tingkat pendapatan wanita pedagang akan meningkat sebesar 0,009

Selain itu dari tabel 2, dapat dilihat bahwa secara parsial modal dan tingkat pendidikan tidak mempunyai pengaruh signifikan terhadap pendapatan wanita pedagang ( $\operatorname{sig} t>0,05)$. Sedangkan variabel lain yaitu jumlah jam kerja, jumlah tenaga kerja, lokasi usaha, pengalaman berusaha mempunyai pengaruh signifikan secara parsial terhadap pendapatan wanita pedagang $(\operatorname{sig} \mathrm{t}<0,05)$

\section{Pembahasan \\ Modal Usaha}

Hasil uji hipotesis yang telah dilakukan bahwa modal usaha tidak signifikan terhadap pedagang wanita sektor informal yang mana modal yang dimaksud modal yang terkait dengan kepercayaan pihak bank terhadap pedagang wanita sektor informal masih rendah, karena pedagang wanita sektor informal kurang bisa memenuhi beberapa persyaratan yang dibebankan oleh pihak bank terutama terkait dengan jaminan atau agunan yang bisa dijaminkan kepada bank untuk memdapatkan pinjaman, sehingga pendagang wanita sektor informal kalau ingin menambahkan modal usahanya tidak lepas dari jeratan "bank thithil" (harian) dengan bunga tinggi sehingga akan membebani usaha yang dilakukan.

\section{Jumlah Jam Kerja}

Hasil uji hipotesis penelitian yang telah dilakukan bahwa jumlah jam kerja berpengaruh positif dan signifikan terhadap pendapatan wanita pedagang sektor informal dalam meningkatkan pendapatan keluarga. Hal ini berarti bahwa semakin panjang jam kerja yang dialokasikan untuk berdagang akan meningkatkan pendapatan wanita pedagang sektor informal yang bersangkutan. Sebaliknya jika jam kerja pedagang wanita sedikit maka akan menyebabkan rendahnya pendapatan wanita pedagang sektor informal. Hal ini sesuai dengan pendapat Arthawa (2012) yang mengemukakan bahwa tambahan jam kerja pedagang informal akan menambahkan jumlah tamu yang berkunjung.

\section{Jumlah Tenaga kerja}

Hasil uji hipotesis yang telah dilakukan menunjukan bahwa jumlah tenaga kerja berpengaruh positif dan signifikan terhadap pendapatan wanita pedagang sektor informal dalam meningkatkan pendapatan keluarga. Hal ini berarti jika wanita pedagang sektor informal memiliki jumlah tenaga kerja lebih banyak akan meningkatkan jumlah pendapatannya karena akan ada pembagian tugas dan pembagian tempat memasarkan barang dagangannya atau berbagi tempat berusaha yang memberikan banyak peluang untuk memperoleh peningkatan pendapatannya. Hal ini sejalan dengan penelitian Santayani (1996) dan Syahruddin (1987), yang menunjukkan bahwa penggunaan tenaga kerja oleh usaha perdagangan informal mempengaruhi tingkat pendapatannya. Dengan tambahan jumlah tenaga kerja, memungkinkan adanya pelayanan yang lebih baik kepada konsumen, baik dalam arti kualitas maupun kuantitas layanan.

\section{Lokasi Usaha}

Hasil uji hipotesis menunjukkan hasil bahwa lokasi usaha berpengaruh positif dan signifikan terhadap peningkatan pendapatan wanita pedagang sektor informal. Hal ini menunjukkan bahwa lokasi berdagang yang ramai dan banyak dikunjungi orang memang akan memberikan peluang untuk terjadi tranksaksi dalam usahanya. Hal ini sejalan dengan (Vera Laksmi Dewi, 2012). bahwa merencanakan suatu usaha perlu memilih letak lokasi usaha yang strategis untuk mudah dijangkau konsumen.

\section{Pengalaman berusaha}

Hasil uji hipotesis terhadap pengalaman berusaha wanita pedagang di sektor informal di wilayah Kecamatan Leces Kabupaten Probolinggo, yang di maksud 
adalah lamanya menekuni pekerjaan sebagai pedagang sektor informal. Hasil uji mempunyai pengaruh positif dan signifikan terhadap pendapatan. Hal ini menunjukkan bahwa pengalaman berusaha akan memberikan pengaruh dalam ketrampilan berusaha. Selain itu itu dengan pengalaman berusaha akan membantu lebih memahami perilaku dan karakter pelanggan sehingga akan berdampak pada pendapatan yang diterimanya.

\section{Tingkat Pendidikan}

Hasil uji hipotesis memberikan hasil bahwa tingkat pendidikan tidak berpengaruh signifikan terhadap pendapatan wanita pedagang sektor informal di Kecamatan Leces Kabupaten Probolinggo, padahal secara teori semakin tinggi tingkat pendidikan akan dapat meningkatkan pengetahuan, kreativitas dan inovasi yang akan meningkatkan kemampuan daya saing. Namun terkait dengan tingkat pendidikan wanita pedagang di sektor informal di Kecamatan Leces tidak berpengaruh signifikan terhadap peningkatan pendapatan wanita pedagang sektor informal karena latar belakang berjalannya usaha mereka secara umum disebabkan karena kemauan yang kuat dan perasaan tidak malu dalam melakukan usaha. Dengan ini tidak sejalan dengan berapa kajian dan penelitian sebelumnya, Arjana (1997) yang menyatakan bahwa pelaku usaha yang terdidik memiliki peluang yang lebih besar untuk meraih tingkat pendapatan yang lebih tinggi.

\section{Kesimpulan dan Saran Kesimpulan}

Setelah dilakukan penelitian dan pembahasan maka dapat di tarik kesimpulan sebagai berikut: 1) Modal usaha tidak mempunyai pengaruh signifikan terhadap pendapatan karena modal yang dimaksud disini adalah modal pinjaman, sedangkan pinjaman modal dari bank membutuhkan jaminan dan administrasi yang dirasa oleh pedagang masih belum fleksibel. Jika terpaksa membutuhkan tambahan modal, pedagang memilih menggunakan jasa pinjaman dari "bank thithil" (harian) meski bunganya tinggi sehingga pada akhirnya malah memberatkan pedagang 2) Wanita pedagang sektor informal apabila ingin meningkatkan pendapatannya perlu menambah memperpanjang jam kerja atau mengatur jadwal jam kerja yang sesuai. 3) Apabila wanita pedagang sektor informal ingin meningkatkan pendapatan dapat menambah jumlah tenaga kerja sehingga menjamin pelayanan yang cepat, pelayanan akan lebih baik dan pembagian kerja yang lebih baik. 4) Lokasi usaha, lokasi yang sesuai tempat yang strategis ramai dan mudah di jangkau akan dapat meningkatkan pendapatan wanita pedagang sektor informal, 5) Pengalaman berusaha, memberikan dampak positif terhadap peningkatan pendapatan wanita pedagang sektor informal karena dengan pengalaman akan semakin banyak kenalan dan pelanggan, dan meningkatkan profesionalismenya. 6) Tingkat pendidikan, tidak berpengaruh secara signifikan terhadap wanita pedagang sektor informal di Kecamatan Leces Kabupaten Probolinggo karena sesuai kenyataan di lapangan pedagang sektor informal tidak memerlukan tingkat pendidikan yang tinggi yang di butuhkan adalah pengalaman, kemauan, keuletan dan kerja keras. 7) Secara simultan modal, jumlah jam kerja, jumlah tenaga kerja, lokasi usaha, pengalaman berusaha, dan tingkat pendidikan telah memberikan kontribusi terhadap pendapatan wanita pedagang sektor informal di Kemacamatan Leces Kabupaten Probolinggo..

\section{Saran}

Sedangkan saran yang dapat diberikan adalah : 1) Terkait dengan modal berusaha perlu adanya perhatian dari pihak pemerintah dalam rangka pemberian pinjaman kepada pedagang informal supaya medapatkan perhatian dan kemudahan dalam pemberian fasislitas kredit yang diberikan oleh pihak bank karena selama ini dirasa masih sulit persyaratannya terutama terkait dengan jaminan. 2) Diharapkan kepada wanita pedagang sektor informal dengan meningkatkan jumlah jam kerja dapat 
menambah pendapatan keluarga, wanita pedagang sektor informal dapat memperhatikan jumlah tenaga kerja agar bisa memberikan pelayanan yang terbaik dan pembagian tugas kerja, lokasi berusaha juga mempunyai peranan penting dalam meningkatkan pendapatan wanita pedagang sektor informal di Kecamatan Leces Kabupaten Probolinggo. 3) Pendapatan wanita pedagang sektor informal dapat dipengaruhi oleh faktor-faktor lain di luar dari variabel bebas (modal, jumlah jam kerja, jumlah tenaga kerja, lokasi usaha, pengalaman berusaha, tingkat pendidikan) yang telah digunakan dalam penelitian di atas, ini memberikan peluang bagi peneliti berikutnya untuk melakukan penelitian yang terkait dengan pendapatan wanita pedagang sektor informal.

\section{DAFTAR PUSTAKA}

Adi Pidekso. 2003. Profil Upaya Perempuan dalam Pemberdayaan Usaha Ekonomis-Produktif Sektor Informal pada Konteks Nilai Pemberdayaan Diri dalam Jurnal Pendidikan Nilai. Kajian Teori, Praktik, dan Pengajarannya. Tahun 9, Nomor 1, November 2003, Universitas Negeri Malang.

Alamsyah, I. 2005. Analisis Nilai Tambah dan Pendapatan Usaha Industri Kemplang Rumah Tangga Berbahan Baku Utama Sagu dan Ikan. Jurnal Pembangunan Manusia. Fakultas Pertanian Universitas Sriwijaya. Palembang

Alcacer, Juan. 2004. Location choices across the value chain: How activity and capability influence agglomeration and competition effects. New York : SternSchool of Business New York University.

Arjana, IG.B. 2007. Faktor-faktor Yang Menentukan Peningkatan Pendapatan Rumah Tangga. Disertasi Program Pasca Sarjana IKIP Jakarta (tidak dipublikasikan)

Artawa, Nama. 2012. Pasar Seni Sukawati Orientasi Sekolah Tinggi Pariwisata Nusa Dua. Gianyar: Dinas Pendapatan Kabupaten Gianyar.

Asmie, Poniwati. 2011. Analisis Faktorfaktor Yang Mempengaruhi Tingkat Pendapatan Pedagang Pasar Tradisional Di Kota Yogyakarta. (tesis). Universitas Gajah Mada Yogyakarta.

Dewi, Vera Laksmi., dkk. 2012. Analisis Pendapatan Pedagang Canang di Kabupaten Badung, Fakultas Ekonomi Universitas Udayana, Denpasar

Ehrenberg, R. G. and R. S. Smith. 1998. Modern Labor Economics. Pearson Education Inc, New York.

Firdaus, A, Dunia. 2013. Pengantar Akuntansi Edisi 4. Fakultas Ekonomi. Universitas Indonesia. Jakarta

Gilbert, J. dan Guglerr. 2006. Urbanisasi dan Kemiskinan di Dunia Ketiga, Edisi Pertama, PT. Tiara Wacana, Yogyakarta

Hidayat, (1993): Situasi Pekerjaan, Setengah Pengangguran dan Kesempatan Kerja di Sektor Informal, Makalah Lokakarya Nasional Angkatan Kerja dan Kesempatan Kerja, November, Jakarta.

Jafar, M.I. 2007. Implikasi Program Keluarga Berencana terhadap Partisipasi Wanita pada Sektor Informal di Kecamatan Soreang Kotamadya Pare-Pare. Tesis Program Pasca Sarjana Universitas Hasanuddin Ujung Pandang (tidak dipublikasikan).

Manning, Chris dan Effendi, Tadjuddin Noer. $1996 . \quad$ Urbanisasi, 
Pengangguran, dan Sektor Informal Di

Kota. Yayasan Obor Indonesia, Jakarta

Manning, Chris., Effendi, Tadjuddin Noer dan Tukiran. 2001. Struktur Pekerjaan, Sektor Informal dan Kemiskinan di Kota. Cetakan kelima. PPK UGM, Yogyakarta

Manning, Chris dan Effendi, Tadjuddin (1995), Urbanisasi, Pengangguran, Dan Sektor Informal Di Kota, Gramedia, Jakarta.

Mosser, Carolina,O.N. 1992. Gender Planning in The Third World: Meeting Practical. Publishing Company.

Munandar, Utami dkk. 2006. Emansipasi dan peran ganda wanita Indonesia: suatu tinjauan psikologis. Universitas Indonesia. Jakarta.

Nicholson, Walter. 1991. Teori Ekonomi Mikro I. Rajawali, Jakarta

Riyanto, Bambang. 2002. Dasar-dasar Pembelajaran Perusahaan. BPPE. Yogyakarta. Sangadji, Etta Mamang dan Sopiah. 2010. Metodologi Penelitian. CV Andi Offset. Yogyakarta.

Santayani. 2006. Peranan Pendidikan dan Pengalaman Berusaha Pada Sektor Informal : Studi Kasus PKL Makanan dan Minuman di Kotamadya Yogyakarta. Skripsi Fakultas Ekonomi UGM Yogyakarta (tidak dipublikasikan).

Samuelson, Paul A. dan William D. Nordhaus. 2002. Makro Ekonomi. Edisi 12 jilid 2. Penerbit Erlangga., Jakarta

Setyawan, A. A. dan M. Fatchurrohman. 2005. Analisis Faktor-Faktor Yang Mempengaruhi Tingkat Upah Sektor Informal Kota Solo. Laporan Penelitian, Universitas
Muhammadiyah Surakarta.

Setyawan, A. A. 2005. Memberdayakan Sektor Informal Perkotaan : Studi Empirik Pedagang Kaki Lima. Usahawan, No. 03, Th. XXXVI, Maret, 41-47.

Sasmita, Asma. dkk. 1983. Pedoman Guru Ketrampilan Khusus Pendidikan Kesejahteraan Keluarga Seri Kegiatan Sehari-hari Untuk SLB Bagian B. Depdikbud. Jakarta.

Sawir, agnes. 2003. Analisis Kinerja Keuangan dan Perencanaan Keuangan Perusahaan. PT. Gramedia Pustaka Utama. Jakarta.

Sukirno, S. 2011. Pengantar Teori Mikroekonomi Edisi Ketiga. PT. Rja Grafindo Persada. Jakarta.

Sutrisno. 2012. Manajemen Keuangan Teori, Konsep dan Aplikasi. Ekonisia. Jakarta.

Suparmoko, M. 2002. Ekonomi Publik, Untuk Keuangan dan Pembangunan Daerah. Andi. Yogyakarta

Syahruddin. 2007. Laporan Penelitian Determinan Pekerja Wanita di Sektor Informal.

Sjahrir, Kartini. 1985. Sektor Informal: Beberapa Catatan Kritis. Prisma, No. 6, tahun. XIV, hal. $74-83$.

Widya Utami, Cristina. 2012. Manajemen Barang Dagangan dalam Bisnis Riteil. Publishing Bayumedia, Malang. 